UDC [620.1'18'19]:[621.793.16]:66.018.8

\title{
INFLUENCE OF DIBENZYL ETHER (DBE) ADDITION ON THE STRUCTURE OF CHROMIUM CARBIDE COATING OBTAINED BY THE MOCVD METHOD FROM COL "BARKHOS"
}

\author{
S.A. Krokhmal, T.N. Zueva \\ National Science Center "Kharkov Institute of Physics and Technology”, \\ Kharkiv, Ukraine \\ E-mail: krokhmal@kipt.kharkov.ua
}

\begin{abstract}
Investigations of the effect of the addition of dibenzyl ether (DBE) to the chromium organic liquid (COL) "Barkhos" on the structure and performance properties of chromium carbide coatings obtained by chemical deposition of their gas phase have been carried out. It is shown that the use of the DBE additive expands the temperature range for the formation of chromium carbide coatings with a horizontally layered structure, which are more resistant to corrosion and erosion wear. In this case, there is an increase in the adhesive strength and cavitation resistance of the coatings. The use of the DBE additive reduces the through porosity of the coatings. Coatings obtained with DBE additives have an abnormally high resistance to electrochemical dissolution in comparison with other materials used for work in corrosive environments.
\end{abstract}

\section{INTRODUCTION}

There is a wide range of coating deposition methods to protect the surface of products from corrosive and erosive wear. One of them is the chemical vapor deposition method. This method makes it possible to apply equal-thickness coatings to products of complex shapes, including their inner surfaces. The use of organometallic compounds as precursors can significantly reduce the process temperature from $1000 \ldots 1100$ to $300 \ldots 550{ }^{\circ} \mathrm{C}$. Chromium carbide coatings are traditionally highly resistant to corrosive and erosive wear. In this work, as a precursor, we used an chromium organic liquid (COL) "Barkhos", produced by an industrial method (TC-1149-78). This technical product contains by-products of synthesis (BPS), which have a negative impact on the quality of the coating.

The structure, size of structural elements and phase composition of the coating determine its physicochemical properties [1-3] and depend on the mode of the deposition process, as well as on the use of various additives to the precursor [4].

It is known that the wear resistance and resistance to plastic deformation of chromium carbide coatings significantly exceed monocrystalline chromium and its carbides [5]. It is also known that these coatings are extremely corrosion resistant to all mineral acids when compared to chromium and its carbides.

It is known that the use of DBE to COL "Barkhos" allows you to reduce the roughness of the resulting coatings and increase their corrosion resistance [3, 4]. Nevertheless, the effect of additives on the performance properties of chromium carbide coatings has not been adequately studied.

In this work, we investigate the effect of dibenzyl ether (DBE) additives on the properties of chromium carbide coatings obtained by chemical vapor deposition using COL "Barkhos" (TC-6-01-1149-78).

\section{EXPERIMENTAL PART}

The deposition of chromium carbide coatings was carried out at reduced pressure on a flow-through installation, a schematic diagram of which is given in [6]. The reaction volume was heated to the required temperature by high frequency currents. DBE (3\%) was added to the original precursor. The temperature of the substrate during deposition was $480 \ldots 500{ }^{\circ} \mathrm{C}$, and the feed rate of the COL "Barkhos" liquid was $7.3 \mathrm{~g} / \mathrm{h}$, with constant evacuation from the reaction zone.

The study of the structure of the coating was carried out on transverse thin sections using the Murakami reagent as an etchant. Cavitation tests were carried out using an ultrasonic generator at a frequency of $20 \mathrm{kHz}$ with an oscillation amplitude of $0.03 \mathrm{~mm}$ in water, while the distance from the emitter to the test sample was $0.5 \mathrm{~mm}$ [7].

A comparative study of the electrochemical dissolution of chromium carbide coatings obtained with and without the use of DBE and the substrate materials on which the coating was applied was carried out on a PI-50-1 setup in the potential range from "- $1 \mathrm{~V}$ " to " $+1.4 \mathrm{~V}$ " in $3 \% \mathrm{NaCl}$ solution.

Since the horizontally layered structure of chromium carbide coatings has the highest resistance to both corrosion and erosion wear $[2,8]$, the temperature of the surface on which the coating was deposited was maintained at the required level. This is the boundary temperature for obtaining chromium carbide coatings with a horizontally layered and columnar structure.

\section{RESULTS AND DISCUSSION}

Transverse sections of coatings with the revealed structure obtained during the experiments are shown in Fig. 1.

The appearance of a more distinct layered structure in the upper part of the coating (see Fig. 1,a) is due to a decrease in the temperature of the pyrolysis surface when the heating of the samples is turned off in the presence of precursor vapors in the deposition zone. 
Further experiments showed that coatings with a horizontally layered structure were obtained at a deposition temperature of $550{ }^{\circ} \mathrm{C}$. Thus, the use of the DBE additive expands the temperature range for obtaining more resistant coatings. It should be noted that the adhesive strength of the coating also increases with an increase in the deposition temperature [9].
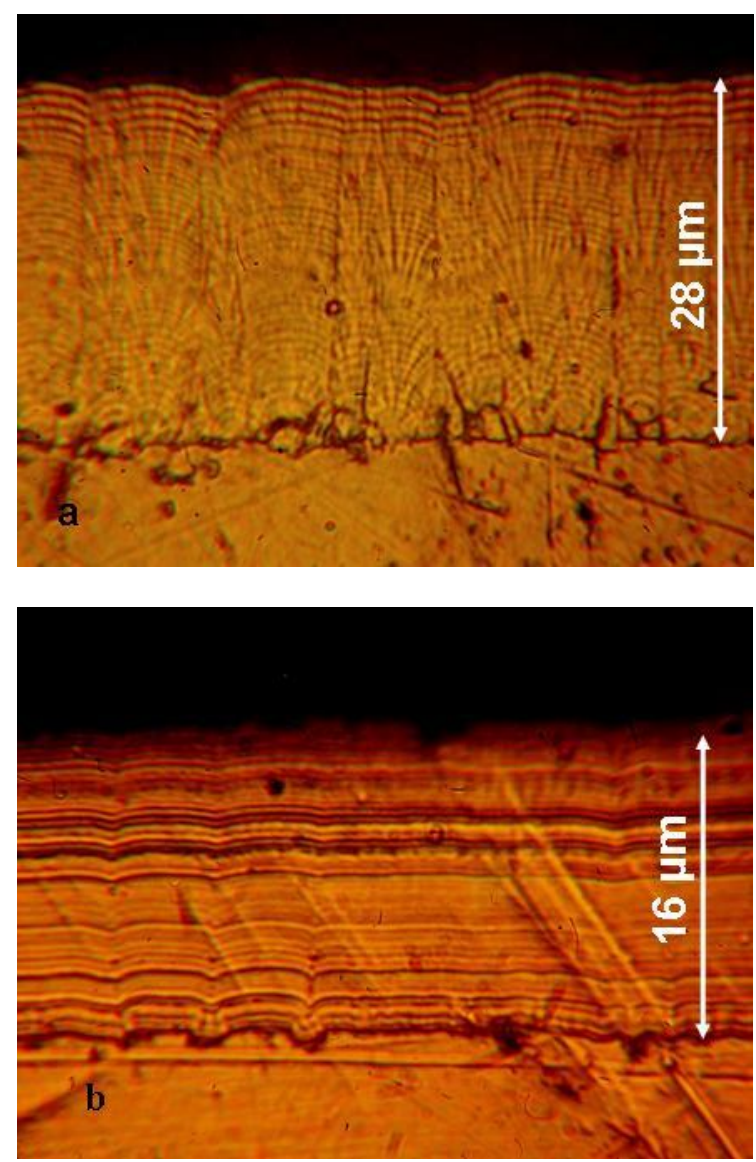

Fig. 1. The structure of chromium carbide coatings obtained without the use of the DBE additive (a) and with the use of the additive (b)

Cavitation tests of coatings showed that coatings with a horizontally layered structure have twice the resistance compared to coatings with a columnar structure, as can be seen from Fig. 2.

' $\Delta \mathbf{m}, \mathbf{m g}$ Cavitation wear of coatings and constructional materials

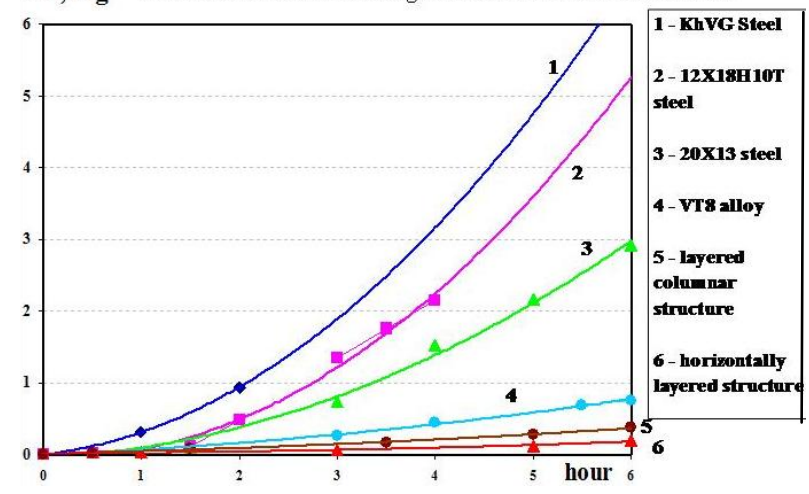

Fig. 2. Dependence of cavitation wear of chromium carbide coatings and structural materials on the test time

At the same time, the cavitation resistance of chromium carbide coatings, both with a columnar and a horizontally layered structure, is 15-25 times higher than the resistance of $12 \mathrm{X} 18 \mathrm{H} 10 \mathrm{~T}$ steel, $8-15$ times higher than that of steel $20 \times 13$ steel and 2-4 times higher than that of alloy BT8 alloy.

Investigations of the electrochemical dissolution of chromium carbide coatings were carried out on samples with a coating thickness of 20 and $21 \mu \mathrm{m}$ obtained at deposition temperatures of $480 \ldots 500{ }^{\circ} \mathrm{C}$ with the use of the DBE additive and without it on substrates made of 08Kh18N10T steel. Potentiostatic curves obtained as a result of tests are shown in Fig. 3. As can be seen from the figure, the coating obtained without the use of an additive in the region of positive potentials begins to dissolve much faster, and the character of the curve completely corresponds to the dissolution curve of the surface of $08 \mathrm{X} 18 \mathrm{H} 10 \mathrm{~T}$ steel. This indicates that the substrate dissolves through the through pores of the coating. And, consequently, in the coatings obtained with the use of the DBE additive from the COL "Barkhos", the absence of through porosity is achieved with a smaller coating thickness.

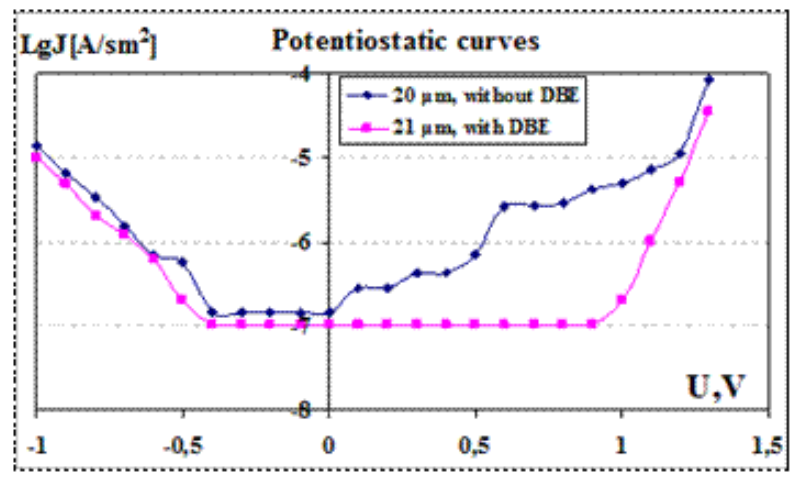

Fig. 3. Potentiostatic curves of chromium carbide coatings obtained with and without the addition of DBE.

Test data obtained on the PI-50-1 installation

Since the values of the current of the potentiostatic curve for the coating obtained using the DBE in the potential range from -0.5 to $+1 \mathrm{~V}$ and the sensitivity of PI-50-1 coincide, it can be assumed that the true course of the curve can be obtained using a more sensitive device.

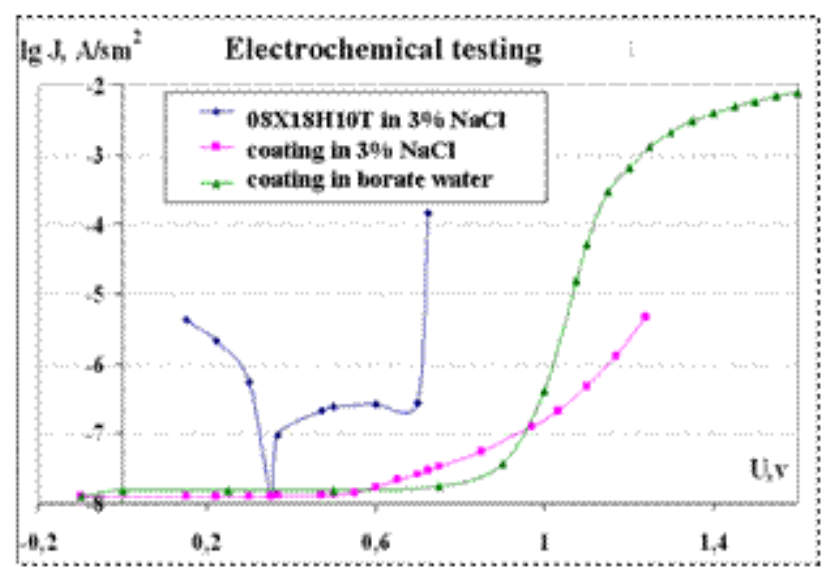

Fig. 4. Coating tests carried out on an IPC-Pro-MF installation in a $3 \% \mathrm{NaCl}$ solution at $20^{\circ} \mathrm{C}$

Using an IPC-Pro-MF potentiostat with an order of magnitude higher sensitivity, the curves shown in Fig. 4 
for substrate and coating material in different test environments.

As can be seen from the figure, the character of the dissolution current curve of the carbide-chromium coating confirms our assumptions about the insufficient sensitivity of PI-50-1. The behavior of the curve of the dependence of current on the applied potential is not typical for such curves, and, therefore, the sensitivity of the IPC-Pro-MF is also insufficient to determine the true course of the curve.

The introduction of the DBE additive makes it possible to suppress the negative effect of BPS, which are present in the cheaper technical product COL "Barkhos", neutralizing their effect on the deposition of a chromium carbide coating, namely, to restrain the formation of larger structural elements of the coating and the formation of through pores in it.

\section{CONCLUSIONS}

The use of the DBE additive expands the temperature range for the formation of chromium carbide coatings with a horizontally layered structure up to $550{ }^{\circ} \mathrm{C}$, which are more resistant to corrosive and erosive wear. In this case, the adhesion strength of these coatings increases with an increase in the deposition temperature. Cavitation tests showed that the resistance of chromium carbide coatings with a horizontally layered structure is two times higher than that of coatings with a columnar structure and significantly exceeds the resistance of some structural materials widely used in industrial production.

The use of the DBE additive reduces the through porosity of chromium carbide coatings obtained by chemical deposition from the gas phase of the COL "Barkhos".

It is shown that chromium carbide coatings obtained with the addition of DBE have an abnormally high resistance to electrochemical dissolution in comparison with other materials used for work in corrosive environments.

\section{REFERENCES}

1. А.С. Лузин, В.Б. Поликарпов, В.А. Додонов и др. Регулирование скорости осаждения, состава и структуры хромкарбидных и хромовых покрытий при термическом разложении металлизационных составов на основе хромоорганической жидкости «Бархос» // Применение металлоорганических соединений для получения неорганических покрытий и материалов: Тез. докл. 5-го Всесоюзн. совещ. Горький, 1987. М.: «Наука», 1987, с. 47-50.

2. Ю.М. Лахтин, Я.Д. Коган, А.П. Горовой, Л.Л. Иванов. Упрочнение режущего инструмента пиролитическими хромовыми покрытиями // Техника, экономика, информащия. Серия «Технология». 1988, в. 4, с. 34-41.

3. В.А. Пашкин, В.А. Гусев, В.Н. Крашенинников и др. Влияние добавки дибензилового эфира на процесс осаждения карбидохромовых покрытий и их свойства // Применение металлоорганических соединений для получения неорганических покрытий и материалов: Тез. докл. 5-го Всесоюзн. совещ. Горький, 1987. М.: «Наука», 1987 , c. $53-54$.

4. В.Б. Поликарпов. Влияние органических соединений на процесс осаждения хрома, молибдена и вольфрама при термическом разложении их $\pi$ комплексов: Автор. дис. ... канд. хим. наук. Горький: ГГУ им. Н.И. Лобачевского, 1986, 24 с.

5. С.А. Крохмаль, Т.Н. Зуева, А.А. Сущая. Структура и свойства многослойных карбидохромовых покрытий, получаемых методом MOCVD из технического продукта ХОЖ «Бархос» // Физическая инженерия поверхности (ФИП). 2016, т. 1, №2, с. 194-206.

6. С.А. Крохмаль, Т.Н. Зуева, Б.М. Широков, Н.А. Семенов. Структурные особенности карбидохромовых покрытий, получаемых методом MOCVD из ХОЖ «БАРХОС» // Проблеми ресурсу $i$ безпеки експлуатаиії конструкичй, споруд та машин: Збірник наукових статей IE3 ім. Є.О. Патона НАН України. Київ, 2015, с. 282-290.

7. В.И. Коваленко, В.Г. Маринин. Исследование разрушения твердых сплавов системы монокарбид вольфрама-кобалът при микроударном нагружении: Препринт. Харьков: ХФТИ АН УССР, 1988, 9 с.

8. Применение металлоорганических соединений для получения неорганических покрытий $u$ материалов / Отв. ред. Г.А. Разуваев. М.: «Наука», 1986, $256 \mathrm{c}$.

9. Ю.М. Лахтин, Я.Д. Коган, А.П. Горовой. Получение защитных покрытий пиролизом металлоорганических соединений // Металловедение и термическая обработка металлов. 1985, №8, c. $30-35$.

\title{
ВЛИЯНИЕ ПРИМЕСИ ДИБЕНЗИЛОВОГО ЭФИРА (ДБЭ) НА СТРУКТУРУ КАРБИДОХРОМОВОГО ПОКРЫТИЯ, ПОЛУЧЕННОГО МЕТОДОМ МОСУD ИЗ ХРОМООРГАНИЧЕСКОЙ ЖИДКОСТИ (ХОЖ) «БАРХОС»
}

\author{
С.А. Крохмаль, Т.Н. Зуева
}

Проведено исследование влияния примеси дибензилового эфира (ДБЭ) на хромоорганическую жидкость (ХОЖ) «Бархос» на структуру и эксплуатационные свойства карбидохромовых покрытий, получаемых химическим осаждением их газовой фазы. Показано, что использование примеси ДБЭ расширяет температурный интервал образования карбидохромовых покрытий с горизонтально-слоистой структурой, более устойчивых к коррозионному и эрозионному износам. При этом происходит повышение адгезионной прочности и кавитационной стойкости покрытий. Применение примеси ДБЭ снижает сквозную пористость 
покрытий. Покрытия, получаемые с примесями ДБЭ, имеют аномально высокую устойчивость к электрохимическому растворению по сравнению с другими материалами, используемыми для работы в агрессивных средах.

\title{
ВПЛИВ ДОМІШКИ ДІБЕНЗИЛОВОГО ЕФІРУ (ДБЕ) НА СТРУКТУРУ КАРБДОХРОМОВОГО ПОКРИТТЯ, ОТРИМАНОГО МЕТОДОМ МОСУD 3 ХРОМООРГАНІЧНОЇ РІДИНИ (ХОР) «БАРХОС»
}

\author{
С.О. Крохмаль, Т.М. Зуєва
}

Проведено дослідження впливу домішки дібензилового ефіру (ДБЕ) до хромоорганічної рідини (ХОР) «Бархос» на структуру і експлуатаційні властивості карбідохромових покриттів, одержуваних хімічним осадженням їх газової фази. Показано, що використання домішки ДБЕ розширює температурний інтервал утворення карбідохромових покриттів з горизонтально-шаруватою структурою, більш стійких до корозійного і ерозійного зносу. При цьому відбувається підвищення адгезійної міцності і кавітаційної стійкості покриттів. Застосування домішки ДБЕ знижує наскрізну пористість покриттів. Покриття, одержувані з домішками ДБЕ, мають аномально високу стійкість до електрохімічного розчинення в порівнянні з іншими матеріалами, використовуваними для роботи в агресивних середовищах. 